\title{
UPAYA MENINGKATKAN KEAKTIFAN BELAJAR MAHASISWA PENDIDIKAN MATEMATIKA DENGAN PENDEKATAN PROBLEM POSING
}

\author{
Syariful Fahmi ${ }^{1}$, Soffi Widyanesti Priwantoro ${ }^{1}$ \\ ${ }^{1}$ Program Studi Pendidikan Matematika FKIP Universitas Ahmad Dahlan \\ Jl. Prof. Dr. Soepomo, SH. Janturan Yogyakarta \\ E-mal: syarifulfahmi@gmail.com
}

\begin{abstract}
Problems in learning introductory computer science which need urgent solution is the problem related with the students learning actinevess. Along with the approach of problem posing, problem solving efforts above got the right momentum. Learning approach used in this research is problem posing approach. The purpose of the research is to increase students' learning activeness. This research activity involves two lecturers and 21 students in course of introduction of computer science at semester 4 academic year of 2015/2016. The data collected using the students activity sheet and analyzed in qualitative descriptive. Based on the results of data analysis it is known that the use of the problem posing approach can raise average students learning on the activeness of cycle 1 that included in the category of low and at cycle 2 is included in the category of middle. It means an increase in students' learning activeness after organized research activities.
\end{abstract}

Keywords: learning activeness, students creativity, problem posing approach

Belajar sebagai proses atau aktifitas dipengaruhi oleh banyak hal/faktor. Faktor tersebut dibagi dua yakni faktor yang berasal dalam diri mahasiswa dan faktor yang berasal dari luar mahasiswa. Faktor yang berasal dari luar mahasiswa meliputi: (1) faktor non sosial seperti keadaan udara, suhu udara, cuaca, waktu dan lain sebagainya, (2) faktor sosial yaitu faktor manusia baik itu manusia hadir secara langsung maupun tidak langsung (lewat foto, lagu, film dan sebagainya). Faktor dari dalam diri mahasiswa sendiri yaitu: (1) fisiologis yaitu kondisi jasmani pada umumnya dan (2) faktor psikologis yang meliputi motivasi, minat, sikap dan lain sebagainya (Suryabrata, 1995:249).

Tugas utama dosen sebagai pendidik adalah mengajar. Dosen dituntut menguasai strategi-strategi atau pendekatan-pendekatan dalam pembelajaran. Dosen diharapkan dapat menyampaikan materi pelajaran kepada mahasiswa secara mudah dengan memperhatikan kecenderungan dan kebutuhan mahasiswa secara umum melaui penguasaan strategi atau pendekatan pembelajaran tersebut. Penentuan 
strategi pengajaran tersebut didasarkan pada pendalaman terhadap dimensi psikologis dan tujuan pengajaran, seperti fakta, konsep, prinsip, prosedur, sikap, pemecahan masalah, dan lain sebagainya (Suparlan, 2005:99).

Pendekatan problem posing merupakan salah satu pendekatan pembelajaran yang mendorong mahasiswa untuk membentuk soal sendiri dan kemudian meyelesaikan soal tersebut (Buletin Pelangi, 2002:33). Dengan metode ini mahasiswa dihadapkan kepada situasi dimana ia diberi kebebasan secara aktif untuk membentuk soal dan menyelesaikan soal. Dosen berfungsi sebagai fasilitator yang mengajak mahasiswa untuk melakukan perumusan soal dan mencoba menyelesaikan soal. Dosen bertindak sebagai penunjuk jalan yang membantu mahasiswa dalam mengungkapkan ide kemudian menggunakannya, menggunakan konsep dan keterampilan yang telah ia miliki untuk membentuk permasalahan dan menyelesaikan permasalahan (Purbasari, 2005:57).

Sejauh pengetahuan penulis, selama ini belum ada penelitian yang menggunakan pendekatan tersebut untuk mewujudkan pembelajaran aktif, kreatif, efektif dan menyenangkan (PAKEM) dalam pembelajaran matematika, khususnya di Pendidikan Matematika Universitas Ahmad Dahlan (UAD), terlebih pada mata kuliah Pengantar Ilmu Komputer. Jadi, menurut hemat penulis, masalah tersebut layak untuk diteliti.

Dari uraian di atas dapat dirumuskan masalah sebagai berikut:
1) Bagaimanakah pembelajaran Pengantar Ilmu Komputer pada mahasiswa pendidikan Matematika Universitas Ahmad Dahlan dengan pendekatan problem posing?

2) Apakah pendekatan problem posing dapat mewujudkan pembelajaran matematika yang aktif, kreatif, efektif, dan menyenangkan?

3) Apa kendala yang dihadapi dosen dan kendala yang dihadapi mahasiswa dalam penerapan pembelajaran dengan pendekatan problem posing?

\section{METODE}

Jenis penelitian mengenai mahasiswa Pendidikan Matematika dengan pendekatan problem posing dalam pembelajaran Pengantar Ilmu Komputer adalah jenis Penelitan Tindakan Kelas (PTK) atau Classroom Action Research (CAR).

Penelitian tindakan kelas ini mengambil bentuk penelitian kolaborasi, yakni mahasiswa bekerjasama dengan dosen mata pelajaran matematika tergabung dalam satu tim untuk melakukan penelitian dengan tujuan untuk menjawab permasalahan di kelas dan untuk memperbaiki praktek-praktek dalam pembelajaran. Hubungan anggota dalam tim kolaborasi adalah bersifat kemitraan, sehingga kedudukan peneliti dan dosen adalah sama untuk berusaha memecahkan permasalahan yang ada di dalam kelas. Secara umum, peneliti dituntut untuk terlibat secara langsung dalam penelitian tindakan kelas ini (Sugiyono, 2015:89). 


\begin{abstract}
Pendekatan yang digunakan dalam penelitian ini adalah pendekatan penelitian kualitatif yakni prosedur penelitian yang menghasilkan data deskriptif berupa narasi atau lisan dari orang-orang tentang perilaku yang dapat diamati (Musfiqon, 2016:76). Penelitian ini dilaksanakan di mata kuliah Pengantar Ilmu Komputer pada mahasiswa semester 4 Pendidikan Matematika UAD.

Instrumen yang digunakan dalam penelitian ini adalah:

1. Lembar Kerja mahasiswa (LKM), merupakan lembar yang dibuat peneliti dan dosen sebagai refleksi terhadap kepahaman dan keterampilan mahasiswa.
\end{abstract}

2. Lembar observasi. Lembar ini berisi catatan yang menggambarkan bagaimana kegiatan belajar mengajar yang dilakukan di kelas, meliputi aktifitas dosen maupun aktifitas mahasiswa. Format lembar observasi adalah format observasi sistematis yeng berbentuk isian, digunakan untuk mengetahui tindakan yang dilaksanakan dalam proses pembelajaran.

3. Dokumentasi berupa foto / gambar yang digunakan untuk menggambarkan proses pembelajaran berlangsung dari segi visual.

4. Angket, yang berupa pernyataan mahasiswa dan dosen mengenai aktivitas dan sikap serta tanggapan yang dilakukan mahasiswa selama proses pembelajaran berlangsung, selain itu juga digunakan untuk mencocokkan data yang diperoleh dalam jurnal harian.
5. Latihan soal dilakukan sebagai alat ukur kepahaman mahasiswa terhadap meteri yang dipelajari.

6. Jurnal harian. Jurnal harian ini berisi catatan kejadian yang belum terdapat dalam lembar observasi. Jurnal ini digunakan sebagai pedoman untuk mengetahui keterlaksanaan proses pembelajaran serta untuk mendeskripsikan aktivitas mahasiswa.

7. Test/soal evaluasi. Test/soal evaluasi ini berupa soal ulangan blok atau pokok bahasan sebagai alat ukur kompetensi mahasiswa terhadap materi yang dipelajari.

Untuk mendapatkan data yang diperlukan dalam penelitian ini dilakukan langkah-langkah sebagai berikut:

1. Melakukan observasi awal dan wawancara dengan dosen mengenai permasalahan yang berhubungan dengan pembelajaran Matematika.

2. Perencanaan yang berhubungan dengan pembelajaran Matematika.

3. Melaksanakan tindakan yang telah direncanakan.

4. Melaksanakan monitoring dengan lembar observasi selama pelaksanaan tindakan, dan wawancara dengan mahasiswa terhadap masalah yang muncul selama proses pembelajaran yang dilakukan setelah pembelajaran selesai.

5. Melakukan refleksi terhadap pelaksanaan pembelajaran.

6. Mendiskusikan dengan dosen tentang tindakan yang akan dilaksanakan selanjutnya.

Langkah-langkah tersebut merupakan aplikasi dari observasi yang dilakukan oleh peneliti dalam 
penelitian tindakan kelas (Sukayati 2002:5).

Perangkat untuk mendapatkan data tersebut selain dengan lembar observasi juga diperlukan angket, lembar catatan harian baik terstruktur ataupun tidak terstruktur, dan pedoman wawancara, juga dokumentasi (foto atau video).

Pada tahap action (tindakan), mulailah diterapkan langkah-langkah pembelajaran yang telah direncanakan semula. Langkahlangkah tersebut yakni (adopsi dari Budiasih dan Kartini dalam Budi Hartati, 2005:56):

1. Dosen Membuka kegiatan pembelajaran

2. Menyampaikan tujuan pembelajaran

3. Menjelaskan secara singkat materi pelajaran

4. Memberikan contoh soal (poin 1, 2, 3, dan 4 kurang lebih 20 menit)

5. Memberikan kesempatan kepada mahasiswa untuk bertanya tentang hal-hal yang belum jelas

6. Memberikan kesempatan kepada mahasiswa untuk membentuk soal dan menyelesaikannya

7. Mengarahkan mahasiswa untuk membuat kesimpulan

8. Membuat rangkuman berdasarkan kesimpulan yang dibuat mahasiswa

9. Menutup kegiatan pembelajaran Pada tahap observing (pengamatan), kegiatan pembelajaran di kelas dicatat atau direkam, dan didokumentasikan. Kegiatan tersebut tidak hanya yang dilakukan oleh mahasiswa, tetapi juga yang dikerjakan oleh dosen/mitra.

Pada tahap reflecting (refleksi), dilakukan pengungkapan kembali apa yang telah dilaksanakan.
Penilaian dilakukan, apakah rencana yang telah disusun dapat terlaksana dengan baik atau tidak. Jika rencana yang tersusun tidak dapat dilaksanakan dengan baik, maka dicarikan jalan keluar bersama mitra/dosen. Penyusunan rencana kembali dilakukan untuk diterapkan selanjutnya.

Model penelitian tindakan kelas Kemmis dan Taggart secara umum dapat digambarkan dalam bentuk spiral action research (Sukayati, 2002:4). Masing-masing spiral terdiri dari empat tahapan, yakni Planning, Acting, Observing, dan tidak cukup satu siklus, yakni setelah tercapai keadaan pembelajaran yang kondusif sesuai rencana. Jika keadaan pembelajaran sudah kondusif sesuai rencana namun target atau tujuan pembelajaran belum benar-benar terwujud maka beralih ke siklus yang lain. Siklus dikatakan lain jika perlakuan yang dilakukan benar-benar berbeda dengan perlakuan sebelumnya. Pergantian sub pokok bahasan bukan berarti pergantian siklus jika perlakuan dalam pembelajaran masih sama dengan sub pokok bahasan sebelumnya (Sukardjono, 2001:4).

\section{HASIL DAN PEMBAHASAN}

Kegiatan pembelajaran terdiri atas dua periode atau siklus. Pada siklus pertama terlaksana dua pertemuan, dan pada siklus kedua terlaksana dua pertemuan, sehingga jumlah keseluruhan adalah empat pertemuan. Hal ini dilakukan dengan harapan tindakan yang dilakukan dalam pembelajaran memperoleh hasil yang baik. Setiap tindakan memiliki metode atau cara pembelajaran yang berbeda tetapi 
masih menggunakan pendekatan problem posing, dan pada setiap tindakan memiliki tujuan pembelajaran yang sama yaitu peningkatan pembelajaran matematika yang aktif. Siklus I menggunakan cara pembelajaran dimana mahasiswa menyusun soal secara individu. Dalam penyusunan soal ini mahasiswa tidak asal menyusun soal, akan tetapi juga mempersiapkan jawaban dari soal yang sedang disusunnya. Dengan kata lain, setelah mahasiswa tersebut dapat membuat soal maka mahasiswa juga dapat menyelesaikan soal tersebut. Tindakan II menggunakan cara pembelajaran dimana mahasiswa menyusun soal dalam kelompok dan kemudian kelompok yang lain berusaha menjawabnya, dimana soal yang telah dibuat kemudian didistribusikan dengan cara penggeseran kepada temannya. Setelah melakukan pengumpulan data dengan menggunakan instrumen penelitian terhadap pembelajaran matematika pada materi penggunaan geogebra dalam menyelesaikan masalah dalam geometri transformasi (refleksi, translasi, rotasi dan dilatasi) dengan menggunakan pendekatan problem posing diperoleh hasil sebagai berikut:

\section{Hasil Tindakan Siklus I}

a. Perencanaan

Adapun kegiatan yang telah dilakukan dalam tahap perencanaan ini adalah sebagai berikut:

1) Membuat rencana pembelajaran dengan menggunakan pendekatan problem posing.

2) Menyiapkan lembar observasi.
3) Menyiapkan lembar kerja mahasiswa (LKM).LKM ini merupakan kumpulan soalsoal yang akan dikerjakan mahasiswa.

b. Pelaksanaan Tindakan

Pada tahap ini dilaksanakan proses pembelajaran sesuai rencana pembelajaran yang telah dibuat.

1) Pertemuan $I$

Pertemuan ini dilaksanakan pada hari Selasa tanggal 14 Juni 2016. Materi pembelajaran tentang mengunakan geogebra untuk materi refleksi. Proses pembelajaran dengan pendekatan problem posing secara deskriptif diuraikan sebagai berikut:

Pada awal pertemuan ini, dosen menjelaskan bahwa pada pembelajaran mulai hari ini memasuki pokok bahasan baru, yakni menggunakan geogebra untuk materi refleksi. Dosen kembali menegaskan jika pembelajaran yang dilaksanakan hari ini sedikit berbeda dengan pembelajaran sebelumnya. Jika sebelumnya dosen menjelaskan kemudian memberikan contoh dan selanjutnya mahasiswa diberi soal untuk dipecahkan, hari ini setelah mendapatkan contoh diharapkan mahasiswa dapat membuat masalah atau soal dan sekaligus mempersiapkan jawabannya.

Dosen berusaha

membangun komunikasi dua arah dengan menanyakan kepada mahasiswa, apakah sudah ada mahasiswa yang belajar di rumah tentang materi 
refleksi. Kecenderungan sebagian mahasiswa memang belum belajar di rumah. Hal ini ditunjukkan dengan jawaban beberapa mahasiswa dengan menjawab "belum". Dosen kemudian menjelaskan tentang fungsi fungsi yang digunakan dalam geogebra untuk materi refleksi.

Dosen melanjutkan pembelajaran dengan menanyakan kepada mahasiswa, apakah sudah jelas atau belum. Beberapa mahasiswa menjawab jelas dan tidak ada suara bisikan yang mengindikasikan mahasiswa belum paham tentang materi yang disampaikan. Dosen yakin jika mahasiswa sudah memahami materi, kemudian memberikan kesempatan kepada mahasiswa untuk mencoba menggunakan fungsi fungsi yang ada di geogebra kaitannya dengan refleksi. Dosen memerintahkan supaya mahasiswa membuat masingmasing contoh dua buah soal yang diselesaikan dengan geogebra. Dosen berkeliling kelas untuk mengecek kesungguhan mahasiswa. Setelah dianggap semua mahasiswa sudah mengerjakan, dosen melanjutkan pembelajaran dengan memberikan kesempatan kepada mahasiswa untuk menunjukkan pekerjaan di hadapan teman kelasnya, yakni dengan jalan mempraktekannya dengan laptop yang dibawa mahasiswa.
2) Pertemuan II

Pertemuan ke-2 dilaksanakan pada hari Selasa tanggal 21 Juni 2016. Pada pertemuan ini dosen melanjutkan pembelajaran ke sub bab selanjutnya, yakni tentang rotasi objek dengan bantuan geogebra. Pada sub bab ini dosen memberikan contoh penggunaan geogebra untuk rotasi. Pada saat itu hampir semua mahasiswa bisa membuat soal rotasi dan menyelesaikannya dengan bantuan geogebra.

c. Refleksi

Dalam merefleksi tindakan yang telah dilakukan pada pertemuan I dan pertemuan II siklus pertama difokuskan pada masalah yang muncul selama pelaksanaan tindakan, berdasarkan hasil pengamatan observasi, jurnal harian dan angket mahasiswa dan dosen serta wawancara tidak terstruktur. Kemudian peneliti bersama dosen mendiskusikannya untuk mengevaluasi keberlangsungan tindakan berikutnya. Dari data hasil lembar observasi, angket, dan wawancara tidak terstruktur terungkap beberapa masalah sebagai berikut:

1. Kebanyakan mahasiswa aktif menjawab pertanyaan manakala dosen menunjuknya dengan menyebut namanya, sehingga keaktifan mahasiswa dalam menjawab pertanyaan atas inisiatif sendiri masih perlu ditingkatkan. Walaupun sudah ada beberapa 
mahasiswa yang menjawab pertanyaan dosen tanpa harus ditunjuk.

2. Dalam membuat soal dan memecahkan soal, mahasiswa masih sering bertanya bertanya pada mahasiswa yang lain, mahasiswa membutuhkan teman yang lain untuk berdiskusi dalam memecahkan soal.

3. Pembelajaran berlangsung masih agak tegang dan kaku sehingga diperlukan pembelajaran yang rileks.

Berdasarkan kondisi dan permasalahan di atas maka perlu dilakukan revisi untuk tindakan selanjutnya, yaitu:

1. Memotivasi mahasiswa untuk terlibat aktif dalam diskusi kelas maupun dalam kerja kelompok, supaya tidak hanya menjadi penonton.

2. Mahasiswa akan diberi kebebasan dalam membuat soal dan memecahkannya bersama dengan teman kelompoknya.

3. Mendorong mahasiswa agar mahasiswa yang sudah paham membantu temannya yang belum paham.

\section{Hasil Tindakan siklus II}

a. Perencanaan

Kegiatan yang telah dilakukan dalam tahap perencanaan ini adalah sebagai berikut:

1) Membuat rencana pembelajaran dengan menggunakan pendekatan problem posing.

2) Menyiapkan lembar observasi.
3) Menyiapkan jurnal.

b. Pelaksanaan Tindakan

Pelaksanaan tindakan pada tahap ini dilakukan sesuai rencana pembelajaran yang telah dibuat.

1) Pertemuan III Pertemuan ini dilaksanakan pada hari Kamis, 23 Juni 2016. Materi pembelajaran yaitu tentang Translasi dengan menggunakan geogebra. Pada pertemuan ini dosen lebih banyak menerangkan tentang fungsi geogebra dalam menyelesaikan soal dan membuat media pembelajaran matematika materi translasi. Kesulitan yang dijumpai mahasiswa adalah dalam membuat media sederhana dengan geogebra, khususnya saat menggunakan fungsi penulisan latex pada penggunaan logika.

2). Pertemuan IV

Pertemuan ini dilaksanakan pada hari Selasa, 28 Juni 2016. Materi pembelajaran tentang penggunaan geogebra untuk menyelesaikan soal tentang dilatasi serta membuat media sederhana dengan geogebra. Pada pertemuan ini mahasiswa perkelompok juga diminta untuk membuat beberapa soal, ataupun memperdalam soal yang telah dibuat pada pertemuan sebelumnya dan meminta kelompok lain untuk memecahkannya. Pada saat ini mahasiswa merasa aktif karena mereka merasa harus membuat soal yang sulit supaya temannya kesulitan dalam memecahkannya. Selain itu mahasiswa juga 
membuat media sederhana dengan geogebra untuk mengenalkan dilatasi.

\section{c. Refleksi}

Refleksi dilakukan berdasarkan tindakan yang telah dilakukan pada pertemuan III dan IV siklus kedua. Refleksi difokuskan pada masalah yang muncul selama pelaksanaan tindakan berdasarkan hasil pengamatan observasi, jurnal harian dan wawancara tidak terstruktur. Hasil observasi, jurnal, dan wawancara tidak terstruktur menunjukkan mahasiswa awalnya kesulitan dalam membuat media sederhana dengan geogebra, namun pada akhirnya mereka mampu menghasilkan produk media sederhana dengan geogebra.

Dari lembar observasi terungkap beberapa hal sebagai berikut:
1) Mahasiswa merasa lebih aktif dalam pembelajaran karena dituntut untuk membuat soal dan temannya yang mengerjakan.

2) Mahasiswa tidak malu untuk bertanya kepada teman dan dosen ataupun mengemukakan pendapatnya di dalam kelas.

3) Mahasiswa berani untuk memberikan tanggapan atas jawaban teman.

Anggota peneliti dan seorang dosen mengunakan lembar observasi untuk memantau kegiatan belajar mahasiswa. Hasil pengisian lembar observasi ini selanjutnya digunakan sebagai data tentang keaktifan belajar mahasiswa selama kegiatan perkuliahan. Data tersebut selanjutnya dianalisi secara deskriptif untuk mengetahui ada tidaknya peningkatan keaktifan belajar mahasiswa. Hasil dari analisis deskriptif tentang keaktifan belajar mahasiswa ditunjukkan pada Tabel 1.

Tabel 1. Persentase skor keaktifan belajar mahasiswa

\begin{tabular}{|c|c|c|c|c|c|c|c|c|c|}
\hline \multirow{3}{*}{ No } & \multirow{3}{*}{$\begin{array}{c}\text { Indikator keaktifan } \\
\text { belajar }\end{array}$} & \multicolumn{8}{|c|}{ Persentase mahasiswa (\%) } \\
\hline & & \multicolumn{4}{|c|}{ Siklus 1} & \multicolumn{4}{|c|}{ Siklus 2} \\
\hline & & $\mathbf{0}$ & $\mathbf{1}$ & 2 & 3 & $\mathbf{0}$ & 1 & 2 & 3 \\
\hline 1. & $\begin{array}{l}\text { Mencari dan } \\
\text { menggunakan } \\
\text { sumber belajar yang } \\
\text { beragam. }\end{array}$ & 57.14 & 28.57 & 14.29 & 0 & 9.52 & 19.05 & 52.38 & 19.05 \\
\hline 2. & $\begin{array}{l}\text { Merespon } \\
\text { pertanyaan yang } \\
\text { diberikan. }\end{array}$ & 71.43 & 19.05 & 9.52 & 0 & 9.52 & 28.57 & 38.10 & 23.81 \\
\hline 3. & $\begin{array}{l}\text { Merespon tantangan } \\
\text { mengerjakan soal di } \\
\text { kelas dengan inisiatif } \\
\text { sendiri. }\end{array}$ & 47.61 & 38.10 & $\begin{array}{c}14.28 \\
9\end{array}$ & 0 & 14.29 & 9.52 & 47.62 & 28.57 \\
\hline 4. & $\begin{array}{l}\text { Bertanya kepada } \\
\text { dosen atau teman } \\
\text { tentang materi yang } \\
\text { belum dikuasai. }\end{array}$ & 38.10 & 38.10 & 23.80 & 0 & 9.52 & 19.05 & 38.10 & 33.33 \\
\hline
\end{tabular}




\begin{tabular}{|c|c|c|c|c|c|c|c|c|c|}
\hline 5. & $\begin{array}{l}\text { Membantu teman } \\
\text { yang mengalami } \\
\text { kesulitan belajar. }\end{array}$ & 71.43 & 19.05 & 9.52 & 0 & 89.52 & 33.33 & 38.10 & 19.05 \\
\hline 6. & $\begin{array}{l}\text { Komunikasi dan } \\
\text { kerjasama dalam } \\
\text { kelompok } \\
\text { (teamwork). }\end{array}$ & 57.14 & 28.57 & 14.29 & 0 & 14.29 & 28.57 & 33.33 & 23.81 \\
\hline 7. & $\begin{array}{l}\text { Komunikasi dan } \\
\text { kerjasama antar } \\
\text { kelompok. }\end{array}$ & 76.19 & 14.29 & 9.52 & 0 & 28.57 & 33.33 & 14.29 & 23.81 \\
\hline
\end{tabular}

\section{Keterangan:}

Skor 0 berarti sama sekali tidak ada aktifitas seperti yang tertulis dalam indikator. Skor 1 berarti ada sedikit aktifitas namun belum bermakna.

Skor 2 berarti melakukan beberapa aktifitas yang bermakna.

Skor 3 berarti melakukan banyak aktifitas yang bermakna.

Data di atas selanjutnya dianalisis untuk diketahui rata-rata skor keaktifan belajar mahasiswa. Ratarata skor keaktifan belajar ini selanjutnya digunakan untuk mengetahui tingkat keaktifan belajar dengan menggunakan kriteria atau kategori pada Tabel 2.
Tabel 2. Kriteria tingkat keaktifan belajar

\begin{tabular}{|c|c|}
\hline $\begin{array}{c}\text { Skor rata-rata } \\
\text { keaktifan } \\
\text { belajar }\end{array}$ & $\begin{array}{c}\text { Tingkat } \\
\text { keaktifan } \\
\text { belajar }\end{array}$ \\
\hline $0,00-0,99$ & Rendah \\
\hline $1,00-1,99$ & Cukup \\
\hline $2,00-3,00$ & Tinggi \\
\hline
\end{tabular}

Tabel 3. Rata-rata dari skor tiap indikator keaktifan belajar mahasiswa

\begin{tabular}{clccc}
\hline No. & \multicolumn{1}{c}{ Indikator keaktifan belajar } & Siklus 1 & Siklus 2 & $\begin{array}{c}\text { Skor } \\
\text { Peningkatan }\end{array}$ \\
\hline 1. & $\begin{array}{l}\text { Mencari dan menggunakan sumber } \\
\text { belajar yang beragam. }\end{array}$ & 0.5715 & 1.8096 & 1.2381 \\
2. & $\begin{array}{l}\text { Merespon pertanyaan yang } \\
\text { diberikan. }\end{array}$ & 0.3809 & 1.762 & 1.3811 \\
\hline 3. & $\begin{array}{l}\text { Merespon tantangan mengerjakan } \\
\text { soal di kelas dengan inisiatif sendiri. }\end{array}$ & 0.66678 & 1.9047 & 1.23792 \\
\hline Bertanya kepada dosen atau teman & 0.857 & 1.9524 & 1.0954 \\
\hline $\begin{array}{l}\text { tentang materi yang belum dikuasai. } \\
\text { 5embantu teman yang mengalami }\end{array}$ & 0.3809 & 1.6668 & 1.2859 \\
\hline $\begin{array}{l}\text { kesulitan belajar. } \\
\text { Komunikasi dan kerjasama dalam } \\
\text { kelompok (teamwork). }\end{array}$ & 0.5715 & 1.6666 & 1.0951 \\
\hline $\begin{array}{l}\text { Komunikasi dan kerjasama antar } \\
\text { kelompok. }\end{array}$ & 0.3333 & 1.3334 & 1.0001 \\
$\quad$ Rata-rata & 0.54 & 1.73 & 1.19 \\
\hline
\end{tabular}


Berdasarkan Tabel 3 diketahui bahwa rata-rata keaktifan belajar mahasiswa pada siklus 1 masuk dalam kategori rendah. Sedangkan setelah dilaksanakan kegiatan siklus 2 dengan menerapkan model pembelajaran problem posing dapat diketahui bahwa rata-rata keaktifan belajar mahasiswa termasuk dalam kategori sedang. Artinya terjadi peningkatan keaktifan belajar mahasiswa setelah diselenggarakan kegiatan penelitian.

Terjadinya peningkatan keaktifan belajar mahasiswa selama mengikuti pembelajaran dengan menggunakan model pembelajaran problem posing dalam rangkaian kegiatan penelitian pada mata kuliah pengantar ilmu pendidikan merupakan kredit tambahan atas manfaat model pembelajaran problem posing dalam pembelajaran matematika. Tabel 1 dan 3 menunjukkan bahwa skor rata-rata pada indikator keaktifan belajar meningkat setelah dilaksanakannya kegiatan siklus 2 dibanding sebelum siklus 2. Indikator ke 1, 4, 5 dari keaktifan belajar merupakan tiga pertama indikator yang memiliki peningkatan skor tertinggi. Sebelum dilaksanakan pembelajaran dengan problem posing, mahasiswa sepenuhnya hanya mengandalkan sumber belajar (khususnya buku cetak) yang diberikan oleh dosen (indikator ke-1). Bahkan sebagian mahasiswa hanya mengandalkan catatan yang dibuat di kelas untuk belajar. Hal ini sudah mulai berubah jika dilihat di akhir pelaksanaan siklus 2, dimana mahasiswa sudah menggunakan sumber belajar yang beragam.
Dari 7 (tujuh) indikator keaktifan belajar yang digunakan, indikator ke-7, yakni komunikasi dan kerjasama antar kelompok, merupakan indikator yang memiliki skor peningkatan paling rendah. Hal ini menunjukkan bahwa, mahasiswa memiliki kecenderungan untuk enggan atau tidak merasa perlu untuk melakukan kerjasama antar kelompoknya. Kebiasaan enggan bekerjasama dengan orang di luar kelompoknya dipicu oleh dorongan berkompetisi antar kelompok yang memang menjadi salah satu bagian pembelajaran yang diharapkan dapat mendorong motivasi belajar. Namun, kompetisi antar kelompok yang dibangun hendaknya tidak sampai menutup ruang kerjasama antar kelompok sehingga mahasiswa tidak terjerumus pada pandangan sempit yang dimiliki kelompoknya saja tanpa mempedulikan pandangan atau ide dari kelompok lain. Sebaliknya, perlu ditumbuhkembangkan pada mahasiswa kebiasaan berbagi ide, gagasan atau solusi dalam menyelesaikan masalah antar kelompok sehingga tercipta ide, gagasan, atau solusi yang lebih komprehensif (Suherman, 2001:65). Kaitannya dengan indikator ke-4, yang merupakan indikator keaktifan belajar yang paling tinggi kategorinya, kenyataan di kelas menunjukkan sangat sedikit mahasiswa yang mau atau berani bertanya pada dosen atau teman tentang materi yang belum dikuasai. Dengan perkataan lain, banyak mahasiswa yang membiarkan ketidakmampuannya menguasai materi sehingga materi yang dipelajarinya tidak dikuasainya dengan tuntas. Padahal dalam 
matematika, penguasaan materi yang satu menjadi prasyarat bagi penguasaan materi berikutnya (Hudoyo, 2005:48). Di akhir pelaksanaan siklus, berdasarkan hasil analisis data dapat diketahui bahwa terjadi peningkatan kriteria pada indikator ke-4, dimana pada siklus 1 termasuk kategori rendah $(0,8)$ dan pada siklus 2 termasuk kategori sedang tinggi (1.95).

Indikator keaktifan belajar yang ke-5, yakni membantu teman yang mengalami kesulitan belajar, merupakan indikator yang penting untuk ditingkatkan, tidak hanya bermanfaat selama kegiatan pembelajaran di kelas tetapi juga dalam kehidupan sehari-hari. Dalam konteks belajar, Vygotsky menyatakan bahwa proses belajar dikelas hendaknya dimunculkan dan dibiasakan terjadi dalam suasana sosial yang kondusif sedemikian sehingga mahasiswa yang mengalami kesulitan belajar akan dapat terbantu baik oleh dosen terlebih lagi oleh teman sebaya (Silberman, 2005:103). Dalam konteks pembentukan karakter bangsa yang merupakan salah satu agenda sistem pendidikan diIndonesia saat ini, pembentukan karakter senang membantu orang lain yang mengalami kesulitan merupakan salah satu tugas besar dunia pendidikan di Indonesia mengingat fenomena di masyarakat dewasa ini menunjukkan semakin memudarnya jiwa tolong menolong dan meningkatnya sifat egoisme serta acuh terhadap masalah orang lain.

\section{SIMPULAN DAN SARAN}

Rangkaian kegiatan penelitian
dengan menerapkan model
pembelajaran problem posing pada mata kuliah pengantar ilmu komputer tahun akademik 2015-2016 telah dapat:

1. Meningkatkan keaktifan belajar mahasiswa semester 4 kelas Unggulan sejumlah 21 mahasiswa.

2. Tingkat keaktifan belajar dalam siklus 1 adalah rendah, setelah siklus 2 meningkat pada kriteria sedang.

3. Peningkatan yang terjadi pada keaktifan belajar bermanfaat tidak hanya secara akademik tetapi juga dalam rangka membentuk karakter mahasiswa yang bermanfaat dalam kehidupan sehari-hari.

Dari hasil penelitian ini yang dapat disarankan sebagai berikut:

1. Dalam pelaksanaan pembelajaran dengan pendekatan problem posing dengan menerapkan kelompok belajar, perlu diperhatikan tentang keheterogenan anggota kelompok sehingga tidak terjadi ketidakseimbangan antar kelompok yang satu dengan yang lain di dalam kelas.

2. Diharapkan dosen mengembangkan Lembar Kerja Mahasiswa yang disesuaikan dengan tujuan pembelajaran dan dikaitkan dengan konteks kehidupan sehari-hari.

3. Dalam proses pembelajaran, variasi dalam pembelajaran baik itu media dan sumber yang digunakan, pengelolaan kelas serta bentuk soal perlu ditambah. 
DAFTAR PUSTAKA

Budi Hartati. (2005). Meningkatkan Kemampuan Mahasiswa dalam Menyelesaikan soal Matematika Melalui Pendekatan Problem Posing di SD Muhammadiyah Tegalrejo. Skripsi. Yogyakarta: UNY.

Hudoyo, Herman. (2005). Pengembangan Kurikulum dan Pembelajaran Matemaika. Malang: UM Press.

Musfiqon. (2016). Metodologi Penelitian Pendidikan. Jakarta: Prestasi Pustaka.

Purbasari, Hanif Yuliana. (2005). Pengaruh Penerapan Pendekatan Problem Posing (Pembentukan Soal) terhadap Minat Belajar Kimia Mahasiswa dan Prestasi Belajar Kimia Mahasiswa Kelas I Semester Ganjil Pokok Bahasan Stoikiometri SMA Muhammadiyah 2 Yogyakarta Tahun Ajaran 2004-2005. Skripsi. Yogyakarta: UIN Sunan Kalijaga.

Silberman, Mel. (2005) Active Learning $101 \quad$ Strategi Pembelajaran Aktif. Yogyakarta: YAPPENDIS.

Sugiyono. (2015). Metode Penelitian Tindakan Komprehensif. Bandung: Alfabeta.

Suherman, Erman dkk. (2001). Strategi Pembelajaran Matematika Kontemporer. Bandung: JICA.
Sukardjono. (2001). Penelitian Tindakan (PT) atau Action Research (AR) atau Penelitian Tindakan Kelas (PTK) atau Classroom Action Research (CAR), Makalah yang disajikan pada Supervisi Pengajaran Matematika untuk Sekolah Menengah pada PPPG Matematika Yogyakarta.

Sukayati. (2002). Penelitian Tindakan Kelas. Makalah yang disampaikan pada Diklat Dosen Pemandu Mata Pelajaran Matematika SD pada PPPG Matematika Yogyakarta.

Suparlan. (2005) Menjadi Dosen Efektif, Yogyakarta: Hikayat Publishing.

Suryabrata, Sumadi. (2012). Psikologi Pendidikan. Bandung: Rajawali Press.

Tim Penelitian Tindakan Matematika SLTPN 4 Sarolangun Jambi. (2002). Meningkatkan Kemampuan Mahasiswa Menerapkan Konsep Matematika Melalui Pemberian Tugas Problem Posing Secara Berkelompok. Makalah yang dimuat dalam Buletin Pelangi Pagi, Vol.5, No. 2 Tahun 2002. 